\title{
Korporatisme-diskussionens selvblokering:
}

\section{Delproblematiseringer af den samfundsmæssige politik- organisation og samfundspolitisk afproblematisering af korporative strategier og strukturer.}

\author{
Hans Kastendiek
}

\section{Indledning}

Vi skal ikke her tage stilling til, om den aktuelle corporatism-debat, som nu også har bredt sig til den vesttyske samfundsviudenskab, udgør et nyt paradigma i Thomas Kuhnsk forstand. Den kan imidlertid sikkert betragtes som et eksempel på, at der, som Kuhn har konstateret, opstår nye analysebegreber, når den eksisterende »normale videnskab « befinder sig i krise. I corporatism-debatten sker der i endnu højere grad end i de aktuelle diskussioner om den »(u)mulige styring « af de vestlige demokrater (jvf. f.eks. Offe 1979a og Douglas 1976) en relativering eller endog en problematisering af nogle af de kapitalistiske demokratiers centrale selvforståelses- og legitimeringsmønstre: i nogle af de mere vidtgående analyseansatser betragtes corporatism som et formmæssigt nyt $\varnothing$ konomisk system eller som en reelt fremvoksende modsætning til pluralisme eller parlamentarisme.

Diskussionen startede i 1974 med en række indlæg,. som tilsyneladende var blevet til uafhængigt af hinanden (Phillipe Schmitter/USA, Gerhard Lehmbruch/Vesttyskland, R.E.Pahl og J.T.Winkler/England, Olof Ruin/ Sverige). Selv om disse diskussionsindlæg undertiden på grund af deres form har kunnet give det indtryk, at corporatismbegrebet her blev benyttet for første gang i forbindelse med analysen af aktuelle udviklingstendenser i vesteuropæiske demokratier, er det en kendsgerning, at dette tema befinder sig indenfor en teoretisk sammenhæng med rødder tilbage til 50'erne og 60'erne (jvf. Lehmbruch 1979d, og f.eks. litteraturhenvisninger hos Ruin 1974): Man kan således finde teser om korporative træk ved den samfundsmæssige politikorganisering i de vesteuropæiske stater efter anden verdenskrig hos f.eks. Shonfield (1965), Beer (1969) og Rokkan (1966). Det nye ved den aktuelle corporatism-debat er således ikke selve omtalen af korporative strukturer; det nye er forestillingen om, at der er sket en dybtgående eller systemomfattende ændring i den samfundsmæssige 
politikorganisering. Som noget nyt kan man iøvrigt også nævne diskussionens »gennemslagskraft«: efter 1974 udviklede den sig til en regulær »vækstindustri« (Panitch 1979a), og den har siden optaget en stor plads i den samfundsvidenskabelige diskussion. Den har således erobret adskillige internationale konferencer som afsætningsmarkeder.

Når diskussionen har haft en sådan »gennemslagskraft«, skyldes det, at den beskæftiger sig med problemer, som i stigende grad har trængt sig på i samtlige kapitalistiske demokratier i forbindelse med den kriseagtige udvikling, siden begyndelsen af 70'erne ${ }^{1}$. Da man var overbevist om at kunne forholde sig til disse problemer på en mere realistisk måde end f.eks. pluralisme- og parlamentarismeteorierne, blev det »nye tema « hyppigt præsenteret med stor selvbevidsthed. Dette fremgår bl.a. af en foromtale til en bog, redigeret af Phillipe Schmitter og Gerhard Lehmbruch, hvori de har samlet nogle af de tidligere (og ikke mindst deres egne) indlæg i diskussionen (Schmitter/Lehmbruch 1979):

»Et fremragende eksempel på et spontant, internationalt og tværfagligt forskningsarbejde, som er udsprunget af en fornyet interesse i korporatisme. Denne bog giver en hård kritik af den hidtidige ahistoriske, konfigurative forståelse af interessegruppernes ageren, af den pluralistiske model og den dominerende empiriske forskningsstil på dette felt. Bidragyderne fors $\varnothing$ ger at opstille et positivt grundlag for en alternativ problematique, idet de lægger vægt på, at en forklaring af aktuelle interessepolitiske mønstre i Vesteuropa, Nordamerika og Japan forudsætter historiske og komparative undersøgelser, som er følsomme overfor langsigtede udviklingstendenser, bestemte begivenheders differentierede virkninger, den akkumulerede betydning af tidligere kritiske beslutninger og den gradvise tilvækst af normative standarder ... et væsentligt bidrag til den løbende debat om interessepolitik og politisk ageren i højt industrialiserede, avancerede kapitalistiske samfund. $\ll^{2}$

Denne tekst er et godt eksempel på, i hvor høj grad mange »corporatister« opfatter sig selv som bærere af en videnskabelig »fornyelse«.

1. Dette gælder ligeledes for den førnævnte diskussion af mulighederne for at regere de vestlige demokratier. Denne diskussion startede også omkring slutningen af 60'erne og tog fart fra ca. 1974; jvf. Douglas 1976, Schmitter 1979, Crouch 1979b og Offe 1979, som beskæftiger sig med sammenhængene mellem de to diskussioner.

2. Forlagsbrochure fra SAGE Publications, London og Beverly Hills, Jan./feb. 1980. Teksten er sammensat af udsagn af Schmitter fra indledningskapitlet; jvf. også Schmitter 1977. 
Mit indlæg i diskussionen godtager ikke denne euforiske vurdering, som ikke blot ser bort fra den hidtidige debats heterogenitet og begrebsmæssige usikkerhed (i den ovenfor omtalte artikelsamling er der således medtaget bidrag som bestemmer, og andre som ikke bestemmer, corporatism som værende i modsætning til pluralisme), men også fra de mange begrebsmæssige og analytiske vanskeligheder, man er stødt på. Efter min mening er debatten præget af visse gennemgående analytiske svagheder, og forslagene til afhjælpningen af disse svagheder er enten lidet overbevisende eller indbyrdes i modstrid med hinanden.

Det er et centralt punkt i mine kritiske bemærkninger i afsnit 2, at de forskellige analysetilgange og corporatism-begreber forholder sig til forskellige delområder eller problemfelter indenfor den samfundsmæssigtpolitiske organisering af herredømmet, og at debatten endnu befinder sig langt fra en fælles problematisering eller fra blot at have opstillet problemstillinger, der kan accepteres som komplementære. Dette beror på, at debatten er domineret af ansatser, som i første omgang afproblematiserer og formaliserer særlige (del-)strukturer indenfor den samfundsmæssige politikorganisation for derefter at ophøje dem til generelle corporatismbegreber. Det er min tese, at de systemkarakteriserende begreber, som er resultatet af denne fremgangsmåde, har ført til en selvblokering af den aktuelle diskussion.

I afsnit 3 vil jeg i tre argumentationstrin fors $\varnothing \mathrm{ge}$ at give et forslag til en re-orientering af corporatism-analysen. Jeg vil forsøge at vise, at de problemkomplekser, som i den aktuelle debat for det meste fremstår uden nogen indbyrdes sammenhæng, kan forståes som problemdimensioner af en corporatism-analyse. Dette skal ske i tilslutning til Schmitters udgangsspørgsmål »Still the century of corporatism? « samt ved at inddrage den (tidligere) korporativisme med autoritært eller fascistisk præg, som Schmitter eksplicit forstår som en subtype af corporatism. Derefter vil jeg begrunde, hvorfor man selv for korporativismen, og i endnu højere grad for de nutidige kapitalistiske demokratiers politikorganisation, må afstå fra et systemkarakteriserende corporatism-begreb. I stedet bør man tale om korporative strukturer indenfor de kapitalistiske magtsystemer. Problemet er altså ikke længere, om der sker en »systemændring « i de kapitalistiske demokratier; man må derimod stille spørgsmålet, hvorfor de korporative strategier og strukturer, som også kan iagttages i dag, opstår, og hvilken samfundsmæssig-politisk funktion de har. 


\section{Hidtidige corporatism-bestemmelser som delproblema- tiseringer af den samfundsmæssige politikorganisation: kritiske kommentarer til den aktuelle debat}

\subsection{Problemkompleksernes heterogenitet.}

Et (ydre) kendetegn ved den aktuelle diskussion om en »ny corporatism « er den inflation, der er gået i begrebet: Især i England, men også i Skandinavien, altså i lande, hvor problemet allerede i flere år har været genstand for en intensiv diskussion, betegner man

- $\quad$ alle mulige strukturelle træk ved stat og samfund,

- $\quad$ alle mulige politiske valg og strategier og

- $\quad$ alle mulige resultater af den samfundspolitiske udvikling

som corporatist $^{3}$. Et andet irritationsmoment er, at man undertiden i stedet vælger at benytte begreberne corporative eller corporativist. Dette har forskellige årsager: undertiden insisterer man på de sidstnævnte begreber, fordi de nu engang har vundet indpas i de pågældende lande (f.eks. i Skandinavien ${ }^{4}$ ); undertiden benyttes corporatism som et begreb med en anden betydning end corporativism (jvf. f.eks. Maier 1975) ${ }^{5}$.

Vigtigere end en strid om ord, er den kendsgerning, at man i de enkelte analyser - oftest uafhængigt af begrebsvalget - focuserer på ret forskelligartede problemkomplekser. Således bliver corporatism/corporativism især tematiseret som

- $\quad$ en voksende statsintervention i den $\varnothing$ konomiske proces' forløb og organisation (Pahl/Winkler 1974, 1976; Winkler 1976, 1977 a b); mere specifikt og med en anden politisk brod som

- $\quad$ en voksende magt og indflydelse til det statslige bureaukrati, som definerer og gennemsætter den statslige agerens imperativer uafhængigt af de politiske flertalsforhold og regeringens partisammensætning og løsrevet og afskærmet fra de samfundspolitiske konflikter (således f.eks. Tony Benn 1979, 1980 fra Labours venstrefløj);

- $\quad$ et problem, der har at gøre med forholdet mellem samfundsmæssigtfunktionelle og politisk-statslige principper for repræsentation og

3. Også i den vesttyske diskussion om »(Neo-)korporativisme« kan man iagttage en stor spændvidde i problemkomplekserne; jvf. Kastendiek 1980, s. 82-85.

4. Jvf. de semantiske henvisninger hos Lehmbruch 1979d.

5. Jeg vender tilbage til forholdet mellem corporatism og corporativism (korporativisme) i 3. del. 
politikudøvelse (således - med mange forskelle - f.eks. Beer 1969; Lehmbruch 1974, 1977, 1979c; Jessop 1978b)

- $\quad$ et organiseret og i stigende grad institutionaliseret samarbejde mellem samfundsmæssige, centrale organisationer og staten ikke blot i forbindelse med den politiske beslutningsproces, men også når beslutningerne skal føres ud i livet (Lehmbruch);

- $\quad$ en statslig kontrol med arbejderklassen gennem integration af først og fremmest dens fagforeningsmæssige organisering i statsapparatet (Panitch 1977, 1979a, 1979b);

- $\quad$ en særlig politik til regulering af industrielle relationer (Crouch 1977, 1979a) eller endnu mere vidtgående som

- $\quad$ en klassepolitisk strategi gennem hvilken kapitalismen underlægger sig den organiserede arbejderbevægelse (Crouch 1979b);

- en desorganisering og fragmentering af arbejderklassen og en partikularisering af dens organisationer, således at arbejderne ikke (længere) optræder samlet overfor kapital og stat, men henvises til at gennemsætte sektorale og/eller faglige delinteresser (Valentin 1978).

I forbindelse med denne opremsning er der især to ting, som falder i øjnene: For det første beskæftiger corporatism-diskussionen sig med problemfelter, som tidligere har været taget op til behandling, og som desuden i en vis udstrækning hører til blandt samfundsvidenskabens traditionelle temaer. For det andet er debatten præget af den opsplitning af samfundsmæssige sammenhænge, som er et alment træk ved videnskaben (jvf. Blanke/Jürgens /Kastendiek 1975:18ff). De tematiske specificeringer er nemlig ikke blot et resultat af forskellige samfundsteoretiske og -politiske positioner; de skyldes i første række den akademiske fagopdeling. Således er der stor forskel på de problemkomplekser og corporatism-begreber, som vælges af hhv. økonomer, sociologer og politologer (jvf. Winkler 1976:102). Indenfor de enkelte fag sker der så en yderligere parcellering: f.eks. behandler politologien denne problematik som en del af hhv. en parlamentarisme-, en parti- og en organisationsanalyse. Denne opsplitning ville ikke udgøre noget problem, hvis disse analyser havde fælles teoretiske og tematiske referencepunkter. Dette er imidlertid ikke tilfældet. Debatten består for en stor del af en konfrontation mellem og en cirkulær diskussion af corporatismbegreber, som er udviklet indenfor rammerne af en anarkisk akademisk »arbejdsdeling «. 


\subsection{Usikkerheden angående problemkompleksernes sammenhæng}

Det har hidtil ikke været muligt at finde en løsning på denne heterogenitet. Som følge af problemkompleksernes og corporatismbestemmelsernes forskelligartethed, har der undertiden bredt sig en næsten resigneret holdning, som er kommet til udtryk i forslag om foreløbig at opgive en synoptisk problematisering og en almen begrebslig afklaring for i stedet at videreføre de foreliggende analyseansatser. Således mener Kurt G. Meier (1978), at det i øjeblikket overhovedet ikke er nødvendigt at sammenfatte de indbyrdes forskellige definitioner. Man skal i stedet bestræbe sig på at gøre problembeskrivelserne så præcise som muligt, således at det i højere grad bliver muligt at efterprøve holdbarheden af de foreliggende ansatser. Arthur Wassenberg ser løsningen i en videreførelse af den empiriske analyse. Det drejer sig om at undersøge »korporatismens faktiske magt, effektivitet eller indflydelse« for at kunne forstå, »hvordan korporatismen virkelig fungerer« (1978c: 1 og 4).

Endelig forsøger Gerhard Lehmbruch at gøre en videnskabelig dyd af den analytiske forlegenhed: debatten kan betragtes som et eksempel, ved hjælp af hvilket »det er muligt at teste teoripluralismens videnskabsteoretiske program« (1979d:4) En væsentlig forudsætning for en sådan test er en afklaring af corporatism-begrebets nationale særtræk. Forskellene er således begrundet i karakteristiske strukturproblemer, politiske kulturer og ikke mindst semantiske forskelle. At disse henvisninger er utilstrækkelige (selv om de sikkert forklarer en del af forvirringen), fremgår af den engelske diskussion. Trods en intensiv og mangeårig corporatism-debat indenfor den engelske samfundsvidenskab, kan man netop her iagttage særlig store forskelle i begrebsdannelse og forskningsansatser. Og i denne henseende er England ikke noget særtilfælde; også diskussionen i f.eks. Skandinavien er præget af særdeles forskelligartede begreber (jvf. f.eks. Ruin 1974 og Valentin 1978).

Selv om Meiers, Wassenbergs og Lerhmbruchs pragmatiske forslag måske kan være rigtige isoleret betragtet, peger de imidlertid ikke ud over debattens eksisterende niveau; de viger nemlig udenom et spørgsmål, som, så vidt jeg kan se, må være helt centralt, nemlig spørgsmålet om, hvilken sammenhæng der er mellem de enkelte problemkomplekser. Denne sammenhæng er så at sige en »black box «i debatten - et punkt, som omtales (hvis det da overhovedet omtales) i vage, hjælpeløse eller ængstelige vendinger.

Således skriver Lehmbruch, at de forskellige begreber ikke 
»er betegnelser for helt forskellige forhold (...) Tværtimod synes de således betegnede fænomener i det mindste at overlappe hinanden så meget, at en vis semantisk tilnærmelse er givet: først og fremmest hersker der enighed om, at visse mønstre i forholdet mellem staten og organiserede $\emptyset$ konomisk-samfundsmæssige interesser på et fremskredet niveau af den kapitalistiske udvikling med bestemte $\varnothing$ konomisk- og samfundspolitiske strategier i hvert fald udgør et væsentligt aspekt ved det betegnede fænomen (...) Åbenbart betegnes delvis forskellige aspekter af et komplekst fænomen selektivt og under partielt divergerende synsvinkler som »korporatisme«. (Lehmbruch 1979d:2f) ${ }^{6}$

Sålænge debatten ikke kommer ud over sådanne almene udsagn om sammenhængen mellem de diskuterede problemkomplekser, er det principielt ikke muligt at afgøre striden om de her problematiserede forholds og udviklingstendensers »corporatism-relevans «. Dermed vil det også (fremover) forblive uklart, på hvilken »alternativ problematik« man skal hæfte corporatism-begrebet.

\subsection{Formaliseringen og den samfundspolitiske afproblematisering i diskussionen om en »ny corporatism «}

En sådan »alternativ problematik « burde - skulle man mene - udmærke sig ved sit samfundspolitiske indhold. Det er imidlertid en af corporatismdebattens største mærkværdigheder, at mange - også af de mere betydende - bidrag næppe eller kun i meget almen forstand lever op til dette krav. De koncentrerer sig om »visse mønstre i forholdet mellem staten og organiserede $\emptyset$ konomisk-samfundsmæssige interesser «, som Lehmbruch udtrykker det i ovenstående citat. De »bestemte $\emptyset$ konomiskog samfundspolitiske strategier«, som han også fremhæver, forsvinder imidlertid stort set ud af billedet. Ofte synes bidragene kun at beskæftige sig med hvorledes de nævnte »mønstre « etableres og opretholdes. Corporatism-analysen forstår sig først og fremmest som et bidrag til en »strukturanalyse « af nutidige kapitalistiske demokrater.

Denne forståelse er mest udpræget og eksplicit blevet formuleret af Schmitter:

6. Heller ikke i Lehmbruchs »Concluding Remarks« i den af ham og Schmitter redigerede artikelsamling bliver der givet en nærmere beskrivelse af »det komplekse fænomen«. Bemærkningerne begrænser sig til en opremsning af nogle af debattens resultater og åbne (enkelt-)spørgsmål. 
»I mit arbejde har jeg fundet det nyttigt at betragte korporatisme som et system til interesse- og/eller holdningsrepræsentation, en særlig måde eller et særligt ideal-typisk institutionelt arrangement til sammenknytning af samfundets (civil society) forenede organiserede interesser og statens beslutningsstrukturer.«(Schmitter 1974:86)

Dette begrundes med, at man kun kan overvinde den vage, flertydige og modsigelsesfyldte brug af begrebet ved at forstå det »operationelt «, som et »operationelt instrument til komparativ analyse « (Schmitter 1974-85, 89): som

»en mere empirisk funderet specificering, som fokuserer på et sæt relativt direkte observerbare, institutionelt udkrystaliserede træk, der har at gøre med den faktiske praksis i forbindelse med interesserepræsentation.« (Schmitter 1974:93)

Ved nærmere eftersyn viser denne begrundelse sig imidlertid at indebære en samfundspolitisk afproblematisering; den reducerer "praksis « til momenter af den samfundsmæssige praksis' institutionelt stivnede strukturer. I første omgang kan det se ud som om Schmitter blot forsøger at hente problemet ned fra ideologiernes og ideernes himmel: »ved at definere korporatisme som praksis, er begrebet befriet fra at skulle tjene en bestemt ideologi eller et bestemt idésystem«. Dette er nødvendigt, fordi en »usædvanlig mangfoldighed af teoretikere, ideologer og aktivister har forsvaret det af vidt forskellige grunde og med vidt forskellige motiver og interesser « (Schmitter 1974:87). Dernæst slår han imidlertid fast: alle direkte eller indirekte corporatism-tilhængere

»har været enige om at forsvare et institutionelt forhold mellem på den ene side systemerne til autoritativ beslutnings-tagning og på den anden side interesse-repræsentations-systemerne, som efter min praksiologiske definition kan betragtes som korporatisk (...), selv om de har sat dette arrangement i forbindelse med radikalt forskellige magtog indflydelsesstrukturer, og har betragtet det som værende til fordel for helt forskellige sociale klasser og som fremmende for diametralt modsatte politiske retninger.« (Schmitter 1974:88, min understregning)

Med andre ord: corporatism lader sig ikke blot reducere til et strukturspørgsmål; som struktur er corporatism allerede tilstrækkelig bestemt, og en sådan bestemmelse kan foretages uafhængigt af indholdet.

Man kan overfor min interpretation indvende, at Schmitter andre steder faktisk har beskæftiget sig med de samfundsmæssigtøkonomiske årsager til corporatism. Således fastslår han f.eks., at de to undertyper state cor- 
poratism og societal corporatism skal betragtes som $»$ resultater af meget forskellige politiske, sociale og $\varnothing$ konomiske processer, som gennemsættelsesbetingelser for meget forskellige magt- og indflydelsesrelationer, og som ophav til meget forskellige politiske konsekvenser « (Schmitter 1974:104f). Imidlertid diskuterer han næsten kun denne problematik i forbindelse med state corporatism; for den mere aktuelle societal corporatism bliver det ved nogle få antydninger, som når han f.eks. skriver, at den må forstås som et fors $\emptyset \mathrm{g}$ på at stabilisere et »bourgeois-dominant regime « (Schmitter 1974:107). Andre bestemmelser af societal corporatisms samfundspolitiske karakter findes ikke; analysen fokuserer til stadighed på det strukturelt-institutionelt stivnede interesseformidlings-system.

Gerhard Lehmbruch fastslår da også, at Schmitters definition »er restriktiv, idet den begrænser sig til organisationsstrukturer og institutionelle forbindelser med staten « (Lehmbruch 1979d:13). Lehmbruch vil undgå den blot formale analyse af den »liberale korporatisme« ved i stedet at betragte den »som en socio-politisk teknik til regulering af klassekonflikten mellem arbejde og kapital og som en måde, hvorpå fagforeninger og arbejdsgiverforeninger inddrages i den statslige (keynesianske) økonomiske styring.« Dette medfører en »vis indsnævring af analysen, idet de store organisationers, især fagforeningernes, »inkorporation «i de statslige styringsmekanismer gøres til det centrale problem «(Lehmbruch 1979 d: 14). Dette er imidlertid ikke den eneste »indsnævring «. Henvisningen - og mere er det ikke - til »regulering af klassekonflikten « er temmelig påklistret, og hertil kommer, at »klassekonflikten« skyndsomst gøres til en »fordelingskonflikt «, i hvert fald for så vidt den formidles gennem det »korporatistiske subsystem « for samarbejde mellem de store organisationer og staten. En tilsvarende reduktion kan iagttages i forbindelse med indsnævringen af »den socio-politiske teknik til regulering af klassekonflikten « (se ovenfor) hhv. det »integrerede system til »samfundsmæssig styring «« (Lehmbruch 1977: 94) til institutionelle samarbejdsformer især på ledelsesniveau (jvf. Lehmbruch/Lang 1977) og til et problem om »etablering af konsensus mellem eliter« (Lehmbruch 1977: 112ff). Også i denne ansats forbliver spørgsmålet om den »liberale korporatismes « samfundspolitiske betydning altså noget ydre ${ }^{7}$.

7. Det skal lige bemærkes, at allerede de få bemærkninger Schmitter og Lehmbruch gør om den aktuelle corporatismes samfundspolitiske implikationer og karakteristika er tilstrækkelige til, at man kan klassificere dem som »quasi-neo-marxister« (Heisler 1979: 281). 
Jeg har valgt at begrunde tesen om corporatism-debattens samfundspolitiske afproblematisering og formalisering ved hjælp af Schmitters og Lehmbruchs bidrag, fordi de befinder sig indenfor hovedstrømmen i den aktuelle diskussion, også således som den er forløbet i den vesttyske samfundsvidenskab. Den manglende samfundspolitiske bestemmelse er ganske vist blevet kritiseret i adskillige bidrag, især af forfattere, som har fors $\varnothing \mathrm{gt}$ at interpretere corporatism indenfor en marxistisk samfundsanalyse (f.eks. Jessop, Panitch, Bonnett). Man må imidlertid erkende, at deres argumentation er utilstrækkelig.

\subsection{Generaliseringen af specifikke strukturer til omfattende corporatism-begreber}

Den samfundspolitiske afproblematisering og formalisering forstærkes yderligere, ved at de enkelte analyseretninger på trods af deres specifikke problemkomplekser har udviklet generelle begreber om en »ny corporatism«. De hævder at have forstået corporatismens konstituerende grundtræk, og nogle af dem har i den forbindelse fundet frem til bestemmelser, hvoraf det fremgår, at der er sket en systemomfattende ændring i den samfundsmæssige og politisk-statslige magtorganisering. Det er her tilstrækkeligt at give en kort fremstilling af nogle af disse begreber ${ }^{8}$. Corporatism bliver forstået som

- $\quad$ et specifikt $\phi k$ konomisk system hinsides kapitalisme eller socialisme. Det er ganske vist endnu kendetegnet ved privat ejendomsret til produktionsmidlerne; men i stigende grad har statslige, halveller quasistatslige instanser overtaget selv den mere detaljerede kontrol med disse (Pahl/Winkler);

- $\quad$ et specifikt system til formidling mellem samfundsmassige interesser hinsides pluralisme eller syndikalisme. Det er præget af eksistensen af særlige, ikke indbyrdes konkurrerende og hierarkisk strukturerede tvangsforbund, som opdeler sig efter funktionelle aspekter, og som anerkendes og reguleres hhv. påvirkes af staten (Schmitter);

- $\quad$ en strukturel differentiering og funktionel specialisering af det politiske system. Ud af de samfundsmæssige hovedorganisationers og statens indbyrdes institutionaliserede tilpasning, især indenfor social-

8. For en mere udførlig fremstilling af de hyppigst diskuterede ansatser se Kastendiek 1980: 85-95). 
politikken og den $\emptyset$ konomiske politik, er der opstået et »sektoralt specialiseret subsystem «, som er karakteriseret ved en forvandling af den organiserede interessepolitik og en ændring af de statslige styringsmekanismer (Lehmbruch);

- $\quad$ en specifik statsform, som er forskellig fra først og fremmest parlamentarismen, idet opnåelse og udøvelse af statslig magt formidles gennem offentlige »korporationer «, som konstituerer sig efter funktionelle aspekter. Denne idealtypiske bestemmelse kan ikke hæftes på konkrete statsformer i de eksisterende kapitalistiske demokratier; disse kan snarere betegnes som et »fremvoksende liberal-korporatistisk trepart-system (tripartite system) «(Jessop $)^{9}$.

Disse fors $\emptyset \mathrm{g}$ på at indkredse og bestemme en »ny corporatism « er udtryk for ret forskellige samfundsanalytiske grundpositioner og interpretationsmønstre:

- $\quad$ Således går Winkler ud fra et temmelig forkortet samfundsbegreb, når han forstår kapitalisme, socialisme og corporatism som $\phi k$ konomisk systemer, eller når han mener, at corporatismbegrebet historisk bl.a. kan bruges i forbindelse med middelalderlige $\varnothing$ konomiske systemer og den $\varnothing$ konomiske politik i det fascistiske Italien (Winkler 1976: 100). Også hans økonomibegreb er forkortet. Det er således næppe tilstrækkeligt at forstå et økonomisk system som »et produktions-, distributions- og byttemønster, som kan karakteriseres ved dets ejerskabs- og kontrolstruktur (dets produktionsforhold) « (Winkler 1976: 103; jvf. Panitch 1979a og Westergaard 1977). På grund af denne reduktionistiske bestemmelse af et $\varnothing$ konomisk system « sker der højst en marginal tematisering af den samfundsmæssigt-politiske magtorganisation.

- Hos Schmitter følger bestemmelsen af analysefeltet som et resultat af en systemteoretisk påvirket opdeling af samfundet: interesseformidlingssystemet bliver betragtet som en særlig strukturenhed ved siden af andre. At dette systems udformning betragtes som det dominerende trak $i$ den samfundsmassige udvikling, skyldes påvirkning fra den nord-amerikanske samfundsvidenskabs gruppe-tradition. De kriterier efter hvilke Schmitter skelner mellem pluralisme og coporatism og

9. Tripartism (tre-part-isme) benyttes først og fremmest i den engelske samfundsvidenskab som en betegnelse for et snævert samarbejde på topniveau mellem stat, kapitalorganisationer og fagforeninger; jvf. Marsh/Grant 1977, som i første omgang generaliserer antagelserne om en »tripartisering «, for derefter at (kunne) bevise deres manglende holdbarhed. 
mellem de to undertyper state og societal corporatism er ganske vist $\mathrm{i}$ højere grad end det er tilfældet hos »pluralisterne « relateret til forholdet mellem samfundsmæssige organisationer og staten; hos Schmitter bliver staten imidlertid ikke gjort til genstand for nogen særlig dybtgående undersøgelse. Statens handlinger er primært at betragte som påvirkning af interesseformidlingssystemet; for Schmitter udmærker det statsligt-politisk herredømme sig følgelig ved den måde, hvorpå det forholder sig til den institutionelt-organisatoriske udformning af dette system.

- $\quad$ Lehmbruch forsøger at lægge afstand til Schmitter ved netop at kritisere dennes fiksering på interesseformidling og interessepolitik. Han beskæftiger sig således mere med det politiske system og den effekt, det har for dette system, at der udvikles nye former for interesseorganisering. I forhold til Schmitter er der tale om et ændret perspektiv: Det spørgsmål, der står i forgrunden, er ikke som hos Schmitter, hvilken funktion den statslige indflydelse har for interesseformidlingen, men derimod spørgsmålet om de politiske funktioner af de store organisationers »inkorporering « i staten. I hvor høj grad dette politologiske-politikfikserede perspektiv dominerer, fremgår af, at analysen orienterer sig i retning af spørgsmålet om, hvorvidt det er muligt at forene den »liberale korporatisme « med »party government«.

- Jessop har ganske vist fors $\emptyset \mathrm{gt}$ at diskutere problemet om forholdet mellem funktionelle og parlamentarisk-statslige principper for repræsentation og politikudøvelse i sammenhæng med politøkonomiske problemstillinger. Hans overvejelser er imidlertid mundet ud i en bestemmelse af corporatism som statsform, som er så skematisk, at den på trods af alle polit- $\varnothing$ konomiske begrundelser minder en hel del om de tidligere juridisk-politologiske statsformsbestemmelser ${ }^{10}$.

De generaliserede bestemmelser, vi har nævnt, er ganske vist forskellige i deres samfundsmæssige placering af problemet og i den måde, hvorpå de begrundes; men metodisk set er de derimod identiske i deres struktur. Dette er især blevet fremhævet af Panitch. Hos først og fremmest Winkler, Schmitter og Jessop ser han

10. Jessop har i mellemtiden relativeret sin ansats, idet han fors $\varnothing$ ger at reformulere corporatism-problematikken ved hjælp af de kategorier, der benyttes i »Gramsci-debatten« (1979a). I et bidrag om den britiske stats udvikling analyserer han først og fremmest corporatism i forbindelse med de industrielle relationer i Storbritannien (1980). 
»en fælles tendens til at give paradigmatiske definitioner af korporatisme i form af ideal-typer, og til at henføre disse definitioner til totale systemer, systemer, som aldrig har eksisteret som beskrevet. De er blot logiske konstruktioner, som er skabt for at kunne fremstå som alternativer til kapitalisme, pluralisme eller parlamentarisme. Denne form for abstraktion er meget forskellig fra den fremgangsmåde, hvor man abstraherer de grundlæggende egenskaber ved en given eksisterende struktur og ser bort fra de historiske og ydre forhold for at nå frem til det grundlæggende forhold, som kan siges at definere strukturen. I forbindelse med korporatisme har vi i stedet set en form for »abstraktion«, som benytter sig af ekspansion i stedet for kontraktion, dvs. en form, som på grundlag af bestemte strukturer udvikler en definition af et helt system, hvad enten der er tale om interesseformidling, statsform eller produktionsmåde. Skønt det sædvanligvis straks indrømmes, at et fuldstændigt korporatistisk system aldrig har eksisteret, og at man mere eller mindre beskæftiger sig med blandingssystemer, gør man ikke desto mindre den antagelse - forankret i selve definitionen - at det er en del af korporatismens natur at udvikle sig i retning af et fuldstændigt system. For at underbygge dette ville det være nødvendigt med en dynamisk historisk teori, som kunne bestemme betingelserne for korporatistiske strukturers udbredelse gennem hele systemet. En sådan teori er ikke blevet fremlagt i blot en af de alternative ansatser.« (Panitch 1979a)

Disse metodiske principper for konstruktion af totalitetsbestemmelser for samfundsmæssige delsystemer forklarer ikke blot den begrebsmæssige forvirring i debatten, hvilket var Panitchs ærinde. Af hans henvisninger fremgår det desuden klart, at vanskelighederne ved at påvise de givne begrebers empiriske håndgribelighed er begrundet $\mathrm{i}$ begreberne selv.

\subsection{Debattens selvblokering}

Hidtil har det ikke kunnet eftervises, at påstanden om en (ny) corporatism er andet end en »stor « hypotese. Man har fors $\varnothing \mathrm{gt}$ og fors $\emptyset$ ger at fastslå dens empiriske håndgribelighed ved en fremgangsmåde, som metodisk blot har karakter af illustrationer, som desuden for det meste er formuleret som tendensudsagn. Dette er ikke den eneste grund til, at henvisningerne til fremvæksten af corporatism-strukturer er utilstrækkeligt dokumenterede; begrebernes og problemkompleksernes heterogenitet indebærer nemlig desuden, at disse henvisninger samlet bevæger sig gennem empirien som en labyrint. Dette er ikke mindst tilfældet når de med henblik på en 
komparativ analyse forholder sig til udviklingstendenser eller udviklingsfaser i forskellige vesteuropæiske kapitalistiske demokratier. Ganske vist kan man for enkelte strukturer henvise til mere eller mindre sikre empiriske fund; men generaliseringen af disse strukturer til totalitetsbestemmelser er imidlertid uden empirisk begrundelse. De idealtypiske konstruktioner er altså at betragte som et produkt af adskillelsen mellem den historiskempiriske analyse og den begrebsmæssige formulering.

De generaliserede bestemmelser optræder imidlertid som udgangspunkt for forsøg på en historisk-empirisk efterprøvning af corporatismtesen. Undertiden synes det som om, man i denne forbindelse går frem efter »ønskekvist«-princippet: udrustet med de foreliggende corporatismdefinitioner går forskningen på jagt efter corporatistiske strukturer; de foreliggende bestemmelser lægges som forudfattede raster ned over den samfundsmæssigt-politiske virkelighed ${ }^{11}$. Idet rasterne kun forholder sig til bestemte samfundsmæssige delområder og problemfelter, må de på den ene side fremstå som værende for sncevre, fordi de ikke kan omfatte alle de problemer, som må anses for at være corporatism-relevante; da disse raster på den anden side generaliserer bestemte strukturer, fremstår de imidlertid også som værende for brede, fordi de bestandig kommer til kort overfor empirien: de viser sig at være inadækvate almengørelser af den konkretaktuelle udformning af både det $\varnothing$ konomiske system, det politiske system og interesseformidlingssystemet (jvf. Nedelmann/Meiers kritik af Schmitter og Nuschelers af Winkler).

\section{Den samfundsmassige politikorganisation som referen- ceramme for korporative strategier og strukturer: Forslag til en re-orientering af corporatism-analysen.}

Efter min opfattelse er det kun muligt at overvinde den ovenfor begrundede (selv-)blokering af debatten, hvis man opgiver disse raster (begreber), som på én gang fremstår som for snæver og for bred. På den ene side drejer det sig om at udvikle begreber for en corporatismanalyse, som ikke snævert forholder sig til enkelte delområder og problemfelter indenfor den samfundsmæssige politikorganisering; på den anden side skal en »ny

11. Temaerne for de talløse konferencepapirer og tidsskriftbidrag rækker fra »Corporatism i Island « til »Corporatism i USA «. 
corporatism《 ikke forstås som et »særligt « system, men derimod som fremvaksten af korporative strukturer indenfor den eksisterende organisering af herredфmmet. I forhold til de hidtil kritiserede begreber er det altså nødvendigt at foretage både en udvidelse og en specificering af corporatism-analysen.

\section{1. »Still the century of corporatism?«}

Efter min mening kan debattens aktuelle stade kun overvindes, hvis man i stedet for

1) den hidtidige formelle og generaliserende typologisering og dennes »taksonomiske forfining « og

2) den pragmatiske fokusering på analysen af enkelte politik- og samfundsstrukturer

forsøger at skabe klarhed over og tilegne sig corporatismens karakteristika og problemdimensioner. Efter vort skøn må sådanne forsøg tage udgangspunkt i den corporatism-form, som indtil idag både som forbillede og som realitet er fremstået med størst klarhed: korporativismen, som den især kendes fra 20'erne og 30'erne. Selv om ordet koporatisme allerede terminologisk adskiller sig fra denne form, er det alligevel netop gennem dette problem- og analysekompleks, at Schmitters spørgsmål »Still the century of corporatism? (1974) får sin mening. For Schmitter er korporativismen (i sin »historiske « form, men også som den eksisterede i Spanien og Portugal til op i 70'erne) en særlig undertype af corporatism, som han kalder state corporatism - til forskel fra societal corporatism, som efter hans mening kendetegner den aktuelle interesseorganisering og -politik i de kapitalistiske demokratier i Vesteuropa. Netop fordi man i dag taler om både en neo-korporativisme (f.eks. på den vesttyske venstrefløj; jvf. Kastendiek 1980: 82-85) og en ny corporatism (den her diskuterede debat), er det ikke muligt at etablere en sammenhæng mellem tidligere og aktuelle former ved hjælp af et abstrakt og generaliseret overgreb (som i den hidtidige debat), men kun gennem en konkret historiskempirisk sammenligning. Til dette formål kan man opløse Schmitters »store spørgsmål « i følgende (del-)spørgsmål:

Er der tale om neo-korporativisme eller om en ny corporatism hvis (fordi)

1) man kan konstatere at korporative strategier og strukturer, som især er blevet udbredt, observeret og kritiseret i forbindelse med de autoritære 
eller fascistiske regimer fra tiden mellem de to verdenskrige, fortsat eksisterer eller opstår på ny?

2) der i stedet i liberale demokratier er opstået tilsvarende, sammenlignelige eller funktionsakvivalente strategier og strukturer?

Det første spørgsmål drejer sig om den eventuelle (fortsatte) eksistens af de særlige træk, som kendetegner state corporatism hhv. den autoritcere korporatisme; det andet om udviklingen af en (anden) form for corporatism, som adskiller sig fra de førstnævnte. De to former kan ikke på forhånd betragtes som eksklusive alternativer i en realanalytisk sammenhæng. Man kan altså yderligere stille spørgsmålet:

3) Kan man i en (eventuel) neo-korporativisme/ny corporatism iagttage momenter af begge former?

Det postulat, at man må analysere begge former, hævdes særlig tydeligt af netop Schmitter, som ganske vist »realiserer « det på den formaliserende generaliserende måde, vi har beskrevet ovenfor. Denne skelnen og dermed også de heraf følgende perspektiver for undersøgelsen af korporative strukturers kontinuitet og forvandling forflygtiges imidlertid i de fleste bidrag efter Schmitter - så vidt jeg kan se ikke mindst i den vesttyske korporatismus-debat. Således peger f.eks. Lehmbruch på nødvendigheden af »en analyse af den autoritære korporatisme af fascistisk observans «: den åbner op for en »videnskabeligt frugtbar typologisk differentiering « (Lehmbruch 1979d: 52f). Denne (temmelige instrumentelle) erkendelsesinteresse realiseres imidlertid kun i begrænset omfang; henvisningen til den »autoritære korporatisme« har egentlig kun den funktion at opstille nogle kriterier ved hjælp af hvilke man på forhånd kan afgrænse den »liberale korporatisme « i forhold til »'stænderordenens' romantisk-reaktionære program« (Lehmbruch 1979d: 53). Derefter kaster argumentationen sig raskt over aktuelle forhold og udviklingstendenser, som har peget i retning af en ny, dvs. en liberal, korporatisme. Således erstatter henvisningerne til et »historisk begreb« den historiske analyse.

\subsection{En corporatism-analyses problemdimensioner}

Det viser sig meget hurtigt, hvor partielle og reducerede begreberne state corporatism og autoritcer korporatisme er, hvis man anvender dem på korporativismen i 20'erne og 30'erne. De her fremherskende modeller og realiseringsfors $\emptyset \mathrm{g}$ kan nemlig ikke betragtes som programmer, som forholder sig til enkelte delområder eller problemfelter, og deres samfundspolitiske målsætninger og implikationer forbyder simpelthen enhver formaliseren- 
de-generaliserende betragtningsmåde. Korporativismens mål var den politiske re-organisering af samfundet, og den klassepolitiske intention var entydigt rettet mod arbejderbevagelsen(s organisationer). Korporativisme skulle være et alternativ til

1) de liberal-demokratiske principper for repræsentation og de muligheder de gav for en politisk artikuleret og ført klassekamp, altså til det bestående partisystem og til parlamentarisme;

2) til den markedsøkonomisk orienterede produktions anarki, som - under de dengang eksisterende verdensøkonomiske betingelser - var en trussel for de nationale økonomiers internationale konkurrenceevne, altså til »fri« фkonomiske konkurrence;

3) til former og resultater af konflikten mellem de socio- $\varnothing$ konomiske grupper(s)/klasser(s organisationer), altså til фkonomisk klassekamp.

I overensstemmelse hermed sigtede de korporativistiske modeller og realiseringsfors $\varnothing \mathrm{g} \bmod$

1) en reorganisering af det politiske system;

2) en restrukturering af nationalфkonomien i retning af en tilpasning af branchestrukturen til verdensmarkedsbetingelser;

3) en regulering og ordning af forholdet mellem lфnarbejde og kapital hhv. deres organisationer.

Modellerne og realiseringsfors $\emptyset$ gene var langt fra identiske, hverken i metode, i rækkevidde eller i hvor de lagde vægten (f.eks. fandtes i forbindelse med reorganiseringen af det politiske system meget forskellige forestillinger om en afskaffelse af parlamentet, om dets delvise bibeholdelse i form af et flerkammersystem eller om dets forvandling gennem en nyordning eller ensretning af partisystemet). Fælles for alle væsentlige opfattelser var imidlertid forestillingen om et »korporativt system «, som skulle forene og harmonisere producentgrupperne og sammenfatte dem i »korporationer«, som så igen skulle udgøre den statslige og den $\varnothing$ konomiske ordens bærende konstitutive enheder (se i denne forbindelse og i forbindelse med de forskellige opfattelser Mayer-Tasch 1971). Korporativisme var altså efter sit mål og sin intention en sarlig klasse-»harmonisk « konstruktion af stat og samfund, som byggede på en direkte og organiseret sammenkadning af politiske, фkonomiske og sociale forhold.

Netop denne »totalitets-betragtning « er imidlertid faldet som offer for den fagopdeling og parcellering af den aktuelle corporatism-debat, som blev fremhævet i afsnit 2.2. De forskellige ansatser generaliserer corporatism på 
bestemte, givne problemniveauer, uden dog at kunne forstå dem som problemdimensioner af det »komplekse fænomen «(Lehmbruch). I det mindste i forhold til korporativismen i 20'erne og 30'erne må man således betegne de hidtidige centrale begreber i corporatism-debatten som reduktionistiske ${ }^{12}$.

Hvis man imidlertid accepterer, at en adækvat analyse af corporatism også må omfatte state corporatism/korporativisme, og ikke mindst, hvis man accepterer, at spørgsmålet om en neokorporativisme hhv. en ny corporatism må formuleres med henblik på den historisk klareste form, må man også bibeholde »totalitets-betragtningen « som problemramme for fors $\emptyset$ gene på at analysere og bestemme en moderne (societal/liberal) corporatism. Dette betyder ikke, at man skal foregribe de mulige resultater af en endnu langt fra afsluttet analyse af den aktuelt eksisterende corporatism. Det kunne jo vise sig, at en moderne corporatism ikke er/behøver at være så gennemorganiseret, som den tidligere model tenderede til. For mig drejer det sig i første omgang kun om, at tydeliggøre det indsnævrede corporatismbegreb, som allerede er indeholdt $\mathrm{i}$ analysens udgangspunkt.

\subsection{Korporativt system eller et net af korporative strukturer?}

Jeg taler om en »totalitets-betragtning « som en problemramme for corporatism-analysen, fordi et totalt corporatism-begreb ikke lader sig formulere som virkelighedsantagelse. Selv i den italienske, tyske, spanske, portugisiske etc. fascisme var der kun tilløb til en realisering af de programmatiske udkast til et korporativt system/en korporativ stat. Det er i endnu mindre grad berettiget at karakterisere de kapitalistiske demokratiers samfundsmæs-

12. Efter Schmitters kriterier for en state corporatism, skulle f.eks. det fascistiske Italiens »korporativstat « betegnes således: et interesseformidlingssystem(!), som i sine væsentlige bestanddele er organiseret i forbund,

- hvis antal fastsættes af staten,

- som på grund af statslige undertrykkelse koncentrerer sig om bestemte forbundsmål, og som ikke konkurrerer indbyrdes,

- som har tvangsmæssigt medlemskab, fastsat i arbejdslovgivningen eller i en anden officiel forordning,

- som på grund af en statsligt pålagt centralisering eller på grund af administrativ afhængighed af staten er hierarkisk strukturerede,

- som under statsligt opsyn har opdelt sig efter fag- eller standskategorier,

- som er sikret statslig anerkendelse,

- som af staten har fået tildelt monopol på at repræsentere deres særlige medlemsskare (Schmitter 1979b: 96f; 1974: 102-105).

At denne operationaliserbare bestemmelse (jvf. afsnit 2.3.) er resultat af en hel række af forudgående operationer/amputationer behøver vel ikke at blive nærmere begrundet. 
sige politikorganisation som helt igennem (neo-)corporatist eller (neo-)korporativistiske, i hvert tilfælde ikke hvis man hermed mener en bred (organisk) gennemorganisering af samfunds- og statsstrukturen efter korporative principper. Hvis vi alligevel opstiller et »totalitets«-begreb, hvad enten det sker i form af et forsøg på at kombinere de hidtidige delbegreber til et metabegreb $^{13}$ eller i form af et fors $\emptyset$ gå at formulere den tidligere model for en autoritær corporatism/korporativisme som et generelt begreb, ville vi blot fortsætte, hvad Leo Panitch med rette har kritiseret: »en samlet tendens til at give paradigmatiske definitioner af korporatisme i form af ideal-typer, og til at henføre disse definitioner til totale systemer - systemer, som aldrig har eksisteret som beskrevet.« (Panitch 1979a; citeret ovenfor i afsnit 2.4.)

Når det altså ikke er muligt at betragte corporatism som et »særligt system « på »subsystem«niveau, dvs. på samme niveau som enkeltstående samfundsmæssige delområder (jvf. afsnit 3.2.), og når man heller ikke, som jeg lige har påpeget, kan gå ud fra eksistensen af et totalt »korporativt system«, så vil det sikkert være fornuftigt helt at opgive forestillingen om, at corporatism kan forståes som et system - i hvert tilfælde for så vidt angår konkrete udformninger af samfund og stat. System-definitioner af corporatism kan kun formuleres som ideal-typer, som når de »anvendes« i realanalyse-sammenhæng, straks må forsynes med tillægsantagelser. Panitchs bemærkninger om, at fremvæksten af corporatism blot udgør en tendens er et eksempel på en sådan tillægsantagelse, som iøvrigt også er immuniserende. Som en anden, ligeledes udbredt, tillægsantagelse kan vi nævne tesen om, at en konkret samfundsmæssig politik-organisering for det meste er en »blandingsform « af flere forskellige idealtypiske organiseringer af herredømmet. Vi har allerede nævnt (jvf. afsnit 2.5.) et af resultaterne af denne tese om en »blandingsform«, nemlig den analysemåde, som består i at klassificere virkelige strukturer efter på forhånd udviklede raster. I modsætning hertil kan man formodentlig betragte det som et positivt skridt, hvis analysen $g \varnothing r »$ blandingsformerne « selv til undersøgelsesgenstand og -udgangspunkt uden først at »bestemme« dem ved hjælp af ideal-typer. Korporative strukturer, om hvis eksistens der i det mindste i den her kommenterede debat hersker enighed, skal altså ikke forstås og undersøges som dele/momenter af et eller andet corporatism-system, men derimod som dele/momenter af en given eksisterende samfundsmassig politikorganisering.

13. For et sådant forsøg se Cawson 1978, som har kombineret Winklers og Schmitters definitioner med hinanden. 
En sådan udvidelse af tema og problemstilling åbner samtidig op for en specificering af korporative strukturer: den konkrete historiskempiriske analyse behøver ikke længere at lade sig blokere af, at sådanne strukturer eksklusivt skulle placeres indenfor enkelte delområder eller -systemer, men kan nu koncentrere sig om korporative organiseringsfors $\varnothing g$ på forskellige niveauer og problemområder indenfor stat og samfund (jvf. Kastendiek 1979 a og b; von Alemann/Heinze 1979b). Til forskel fra mange andre, som sætter lighedstegn mellem corporatism og treparts-strukturer på topniveau, har f.eks. Leo Panitch fremhævet, at corporatism kunne være et meningsfyldt problem at tage stilling til, hvis man dermed mener »en politisk struktur indenfor den fremskredne kapitalisme, som integrerer organiserede socio $\varnothing$ konomiske producent-grupper gennem et system af repræsentation og samarbejde på lederskabs-niveau og mobilisering og social kontrol på masseniveau « (Panitch 1977: 66; mine understregninger); Arthur Wassenberg (1978a og b) har foreslået at man differentierer og specificerer de korporative strukturer som forekommer i forbindelse med organisering og beherskelse af de økonomiske processer og industrielle relationer, efter

- $\quad$ et mikro-niveau (bedrift, virksomhed),

- $\quad$ et meso-niveau (branche, region) og

- $\quad$ et makro-niveau (central-statslige instanser og overordnede sammenslutninger).

Angående de forskellige politik-felter, hvor man kan iagttage korporative strategier og strukturer, skal vi her blot understrege, at de - i modsætning til hvad man sædvanligvis antager - ikke kun findes indenfor det indkomstpolitiske område, hvor de øvrigt sikkert heller ikke gør sig gældende med større vægt, og heller ikke kun indenfor området af industrielle relationer i snæver forstand. Man kan i denne forbindelse henvise til undersøgelser af corporatism i England, hvor det netop understreges, at industripolitikkens organisering i bred forstand er præget af korporative eller i det mindste treparts-strukturer; vi kan også her gøre opmærksom på den nyere tyske diskussion om neokorporatisme, som lægger større vægt på strukturpolitikken end på indkomstpolitikken (jvf. Kastendiek 1980, 83 og 102).

I forbindelse med denne ansamling af korporative strukturer på forskellige niveauer og politikfelter må man undersøge, om der indenfor den eksisterende organisering af herredømmet i de kapitalistiske demokratier i Vesteuropa har udviklet sig et net af korporative strukturer, som gensidigt påvirker, kompletterer og understøtter hinanden. Spørgsmålet om for det 
første et sådant nets indre sammenhæng og for det andet dets betydning for og indflydelse på den eksisterende organisering af herredømmet kunne da betragtes som en hovedopgave for corporatism/korporativisme-analysen.

\subsection{Korporative strategier og strukturer som forsøg på at forbinde det økonomiske og det politiske herredømme}

Ved besvarelsen af dette spørgsmål om korporative strategier og strukturers forhold til hinanden og om deres sammenhæng med kapitalistiske demokratiers samfundsmæssige politikorganisation kan man, så vidt jeg kan se, gå i to forskellige analyseretninger:

Den første følger den antagelse, at de hidtil hævdede eller fastslåede korporative strukturer i det $\varnothing$ konomiske og politiske system hhv. i »interesseformidlings-systemet « (på en måde, som behøver en nærmere bestemmelse) svarer til hinanden, således at den samfundsmæssige udviklingstendens (som også behøver en nærmere bestemmelse) giver anledning til den samme eller til en parallel strukturel ændring i de forskellige »subsystemer«. Dette forudsætter naturligvis, at den hidtidige alternativ tilskrivning af korporative strukturer til et af de forskellige »subsystemer « opgives, hvilket også som totalsystemmæssig problematisering ville udgøre et fremskridt i forhold til den hidtidige opdeling af samfundsmæssige sammenhænge (jvf. afsnit 2.1.). På den anden side ville fremskridtet være begrænset af, at korporative strukturer stadigvæk blev betragtet som tilh $\varnothing$ rende enkelte »subsystemer « (selv om der her er tale om flere).

Den anden analyseretning, som jeg selv er fortaler for, opgiver i modsætning hertil helt at rubricere korporative strukturer i enkelte delsystemer, for i stedet at interpretere korporative strukturer som fors $\phi g$ på direkte og organiseret at sammenknytte samfundsmassige delområder. Denne forklaringsansats går ud fra, at den karakterisering af korporativistiske modeller, som blev givet $i$ afsnit 3.2., også er gyldig for korporative strukturers fremvækst i de kapitalistiske demokratiers samfundsmæssige politikorganisation (hvilket ikke betyder, at de forskellige fors $\varnothing g$ på at gennemsætte en direkte og organisatorisk sammenknytning af det samfundsmæssigt- $\varnothing$ konomiske og det statsligt-politiske herredømme nødvendigvis er identiske; jvf. forskellen mellem en societal og en state corporatism hos Schmitter og tilsvarende differentieringer hos andre forfattere).

I første omgang kan vi konstatere, at den forklaringsansats, jeg har foreslået, underst $\varnothing t t e s$ af mange af de hidtidige corporatismanalysers 
og -diskussioners (enkelt-)resultater: på trods af, at det sædvanlige corporatism-begreb forholder sig til et (del-)system, altså på trods af den eksklusive placering af en formodet (ny) corporatism i det $\varnothing$ konomiske eller i det politiske system eller i »interesseformidlings-systemet « beskæftiger man sig alligevel til stadighed med »bestemte relationsmønstre (jvf. Lehmbruch-citatet i afsnit 2.2.), især mellem økonomiske og politiske aktører, dermed også mellem politik og økonomi hhv. stat og økonomi. Det er derfor nærliggende at betragte denne relation som et alment træk ved korporative strukturer.

Det skal så undersøges, om korporative strukturer hjælper (skal hjælpe) med at »løse « et problem, som er et iboende moment $i$ et kapitalistisk udformet samfund: problemet med at etablere en sammenhæng mellem samfundsmæssige delområder eller sfærer, som er eller skal være »relativt autonome «. Iøvrigt definerer kapitalistiske demokratier jo sig selv som samfundsindretninger, hvor herredømme- og magtrelationerne er uddifferentierede i sociale, økonomiske og politiske relationer, som også skiller sig ud institutionelt (at dette ikke blot er en »illusion«, er grundigt blevet diskuteret i den såkaldte »statsudlednings-debat «, som jo i stor udstrækning ikke var en statsdebat i snæver forstand, men en marxistisk kontrovers over forholdet mellem politik og økonomi i det borgerlige samfund; jvf. bl.a. Blanke/ Jürgens /Kastendiek 1975; især kap. 16-19). Dermed opstår et permanent problem, nemlig at etablere den samfundsmæssige syntese, og den instans, som skal løse dette problem fremstår indenfor de forskellige samfundsteoretiske positioner som hhv. staten, det politiske system, kapitalen etc. Selv om det var muligt teoretisk at begrunde, at denne syntese ikke kan betragtes som en permanent ex post-handling, som afstemmer udviklingen i de forskellige samfundsmæssige områder/sfærer efter hinanden, men derimod så at sige som en forudgående indbyrdes afhængighed mellem delområderne/sfærerne, som en i det borgerlige samfund systematisk nedlagt »indre formidling « især mellem politik og økonomi (jvf. på ny Blanke/Jürgens / Kastendiek 1975), opstår det problem, hvilke direkte forbindelser mellem de enkelte sfærer denne syntese er henvist til: den »indre formidling « virker jo ikke blot som en »invisible hand «, men konstituerer sig i personers, gruppers, klassers og samfundsmæssige institutioners konkrete handlinger.

Dette problem fremstår i skærpet form i faser af den samfundsmæssigtpolitiske udvikling, hvor den kapitalistiske samfundsmæssigg ørelses »normalitet « er truet, hvad enten der er tale om tider, hvor den trues udefra 
(krig), tider med en kriseagtig økonomisk udvikling og/eller tider, hvor klassekonflikten er tilspidset. I forbindelse med den aktuelle corporatismdiskussion er det ofte blevet påpeget, at det netop er i en sådan situation, at kravet om en »sammenfatning af alle samfundsmæssige, $\varnothing$ konomiske og politiske kræfter « har fundet og finder udtryk i korporative strukturer og strategier. Der tænkes her ikke blot på autoritære eller fascistiske forestillinger om en ophævelse af demokratiske forfatningsprincipper. Det gælder også for kapitalistiske demokratier især siden den første verdenskrig (jvf. Bowen 1947; Maier 1975; Harris 1972; Middlemas 1979). Åbenbart viser det sig også i disse samfund bestandig »historisk « nødvendigt direkte og undertiden endog institutionelt at sammenfatte separat organiserede sociale, $\varnothing$ konomiske, politiske, ideologiske etc. herredømmerelationer ${ }^{14}$. På grund af sin idealtypiske modstilling af på den ene side kapitalisme, pluralisme og parlamentarisme og på den anden side corporatism har corporatism-debatten ikke engang været i stand til at stille det spørgsmål, om de korporative strukturer, som man betragter som »systemfremmede « for de kapitalistiske demokratier, under visse omstændigheder kan betragtes som kendetegnende for netop dette herredømme-system.

\section{Afsluttende bemærkninger}

At forsøgene på at forpligte de samfundsmæssige »producentgrupper« til at følge klasseharmoniske former for samarbejde og konfliktregulering især er rettet mod fagforeningerne ${ }^{15}$, skyldes ikke, at der her er tale om en vigtig »interessegruppe «; den korporative båndlæggelse af fagforeningerne er til stadighed nødvendig, fordi de udgør den økonomiske masseorganisering og fordi de forsvarer »massernes « $\emptyset$ konomiske interesser. Som sådan står de ikke blot overfor kapitalen og dens organisationer; som masseorganisationer

14. Heller ikke i den (vest-)tyske samfundsvidenskab er dette nogen ny tese. Den forekommer først og fremmest i den genoptagne debat om en »organiseret kapitalisme« (H.A. Winkler 1974), i teorierne om den »den statsmonopolistiske kapitalisme« eller om »sen-kapitalismen«. Det er/ville sikkert være en vigtig opgave, endnu engang at gennemarbejde disse teorier i forbindelse med problemstillingen corporatism/korporativisme. Schmitters fors $\emptyset \mathrm{g}$ herpå er helt utilstrækkeligt (jvf. Schmitter 1977).

15. Jvf. især Panitchs og Crouchs værker, der fremhæver dette problems centrale placering i forbindelse med corporatism, og dermed gennembryder den formaliserede og afproblematiserede betragtningsmåde, som har domineret i den hidtidige debat; jvf. endvidere Streecks værker, hvis udsagn imidlertid ofte er organisationssociologisk indsnævrede. For et fors $\emptyset \mathrm{g}$ på med Vesttyskland som eksempel at eftervise tesen om »fagforeningernes inkorporering « se Hans Kastendiek, Hella Kastendiek, Hugo Reister 1981. 
står de også potentielt i et konkurrence- og konfliktforhold til partier/regeringer/ statsapparater, som jo gør krav på at (ville) være »massernes « politiske repræsentanter eller »beskyttere «. Efter min opfattelse er corporatism/korporativisme-analysens vigtigste problemstilling, at undersøge hvorledes man også i de (eksisterende) kapitalistiske demokratier forsøger at oprette korporative strukturer i form af særlige »masseintegrationsstrategier« (Hirsch) Roth 1977) for den samfundsmæssigt-politiske orden.

Netop dette problem er imidlertid stort set blevet negligeret i de hidtidige »strukturanalyser « af (den nye) corporatism (jvf. afsnit 2.3.). Formodentlig var det netop kun på grund af den formalisering og samfundspolitiske afproblematisering af korporative strukturer, som jeg tidligere har beskrevet, at det var muligt med held at udbrede det »nye tema«. Dette fremgår også af den vesttyske samfundsvidenskabs forhold til corporatism-debatten. Den begyndte således først-efter årtiers afstandtagen - at beskæftige sig med spørgsmålet om eksistensen af korporative strukturer, efter at dette spørgsmål var blevet støbt i relativt tillidvækkende (sprog-)former og analyse-begreber.

Oversat af Mogens Andersen fra Ulrich von Alemann (ed.) Neokorporatismus, Frankfurt a. M. 1981. 


\section{Litteratur}

Alemann, U.v., Heinze, R.G., 1979 a: Auf dem Weg zum liberalen Ständestaat?. Einführung in die Korporatismusdiskussion, in: dies., 1979c, s. 38ff.

Alemann U.v., Heinze, R.G., 1979 b: Neo-Korporatismus. Zur neuen Diskussion eines alten Begriffs, in: Zeitschrift für Parlamentsfragen, Jg. 10, Heft 4, s. 469ff.

Alemann U.v., Heinze, R.G. (Hg.), 1979 c: Verbände und Staat. Vom Pluralismus zum Korporatismus. Analysen, Positionen, Dokumente, Opladen, 2. opl. 1981.

Beer, S. 1969: Modern British Politics, London (1. gang 1965).

Benn, T., 1979: Arguments for Socialism, London.

Benn, T., 1980: The mandarins in Modern Britain..., in: The Guardian, 4.2. 1980, s. 9.

Blanke, B., Jürgens, U., Kastendiek, H., 1975: Kritik der Politischen Wissenschaft, 2 bd., Franfurt/New York.

Bonnett, K., 1978: Corporatist Developments in Advanced Capitalist Society: Competing Theoretical Perspectives, bidrag til SSRC Institutionalisation Conference på Institute of Development Studies University of Sussex, sep. (mangfoldiggjort manus).

Bowen, R.H., 1947: German Theories of Corporative State, New York.

Cawson, A., 1978: Pluralism, Corporatism and the Role of the State, in: Government and Opposition, vol. 13 , no. 2 , s. $178 \mathrm{ff}$.

Crouch, C., 1977: Class conflict and the Industrial Relations Crisis. Compromise and Corporatisme ind the Politics of the British State, London.

Crouch, C., 1979 a: The Politics of industrial Relations, London/Glasgow.

Crouch, C., 1979 b: The State, Capital and Liberal Democracy, in: ders., (udg.), State and Economy in Contemporary Capitalism, London, s. 13ff.

douglas, J., 1976: Review Article: The overloaded Crown, in: British Journal of Political Science, vol. 6 , s. $483 \mathrm{ff}$.

Harris, N., 1972: Competition and the Corporate Society. British Conservatives, the State and Industry 1945-1964, London.

Heisler, O., 1979: Corporate Pluralism Revisited: Where is the Teory?, in: Scandinavian

Political Studies, vol. 2, new series, No. 3, s. 277ff.

Hirsch, J., Roth, R., 1977: Von der ökonomischen zur politischen Krise. Perspektiven der

Entwicklung des Parteiensystems in der BDR, in: links 92, oktober, s. 9ff.

Jessop, B., 1978 a: Capitalism and Democracy: The Best Possible Political Shell, in: G. Littlejohn (udg.), Power and the State, London, s. 10ff.

Jessop, B., 1978 b: Corporatism, Fascism and Social Democracy, papir til ECPR-Workshop »Corporatism in Liberal Democracies« i Grenoble, april, revideret udgave in: Schmitter, Lehmbruch, (udg.), 1979.

Jessop, B., 1979 a: Corporatism as Passive Revolution: a discussion paper, papir til CSE-konference sommeren 1979. (Mangfoldiggjort manus).

Jessop, B., 1980: The Transformation of State in Postwar Britain, in: Scase, R., ed., The State in Western Europe, London: Croom Helm.

Kastendiek, Hans, 1979 a: Konzeptionelle Probleme der Korporatismus-Analyse, papir til 10. Arbeitstagung des Arbeitskreises »Parteien - Parlamente - Wahlen« der Deutschen Vereeinigung für Pol. Wiss. in Neuss, (mangfoldiggjort manus).

Kastendiek, Hans, 1979 b: Corporatist Structures - an Organizational Network of Economic and Political Relations, papir til ECPR-Workshop »Autority in Industrial Societies« i Bruxelles, april, (mangfoldiggjort manus).

Kastendiek, Hans, 1980: Neokorporativismus? Thesen und Analyse-Konzepte in der westdeutschen Disskusion und in der internationalen »corporatism«-Debatte, in PROKLA 38, 10. årg., april, s. 81ff. 
Kastendiek, Hans, Kastendiek, Hella, Reister, Hugo, 1981: Inkorporierung der Gewerkschaften? in: Alternative Wirtschaftspolitik 3, Argument-Sonderband, Berlin.

Lehmbruch, G., 1974: Consociational Democracy, Class Conflict and the New Corporatism, papir til Round-Table i International Political Science Association i Jerusalem, sep., in: Schmitter/ Lehmbruch, (udg.), 1979.

Lehmbruch, G., 1976: Liberal Corporatism and Party Government, Revised version of a paper presented to the IPSA World Congress, Edinburgh, s. 50.

Lehmbruch, G., 1977: Liberal Corporatism and Party Government, in: Comparative Political Studies, vol. 10 no. 1, april, s. 91ff. in: Schmitter/Lehmbruch, (udg.), 1979.

Lehmbruch, G., 1978: Corporatism, Labour and Public Policy, papir til symposiet »Social Policies in Comparative Perspective « 9. verdenskongres for sociologi i Uppsala, august, (mangfoldiggjort manus).

Lehmbruch, G., 1979 a: Concluding Remarks:Problems for Future Research, in: Schmitter, Ph. Lehmbruch (udg.), Trends Toward Corporatist Intermediation, London/Beverly Hills: Sage, s. 299ff. Lehmbruch, G., 1979 b: Wandlungen der Interessenpolitik im liberalen Korporatismus, in: Alemann, U.v., Heinze, R.G. (1979 c), s. $50 \mathrm{ff}$.

Lehmbruch, G., 1979 c: Parteiensystem und Interessenverbände in der Politikentwicklung, in: Matthes, J. (udg.), Sozialer Wandel in Westeuropa, Frankfurt/New York, s. 591ff.

Lehmbruch, G., 1979 d: Einige Entwicklungslinien und Probleme in der »Korporatismus Diskussion, papir til 10. Tagung des Arbeitskreises »Parteien-Parlamente-Wahlen« der Deutschen Vereinigung für Pol.Wiss. in Neuss, (mangfoldiggjort manus).

Maier, Ch. S., 1975: Recasting Bourgeois Europe, Stabilization in France, Germany and Italy in the Decade after World War I, New Jersey.

Marsh, D.W., Grant, W., 1977: Tripartism: Reality or Myth? in: Government and Opposition vol. 12,1977 , s. $194 \mathrm{ff}$.

Mayer-Tasch, P.C., 1971: Korporativismus und Autoritarismus. Eine Studie zu Theorie und Praxis der berufsständischen Rechts- und Staatsidee, Frankfurt.

Meier, K.G., 1978: Corporatism and Interest intermediation. Some Comments on Areas for Research, papir til ECPR-Workshop »Corporatism in Liberal Domocracies « in Grenoble, april 1978, (mangfoldiggjort manus).

Middlemas, K., 1979: Politics in Industrial Society. The Experience of the British System since 1911, London.

Nedelmann, B., Meier, K., 1977: Theories of Contemporary Corporatism, Static or dynamic? in: Comparative Political Studies, vol. 10 no. 1, april 1977, s. 39ff. (nu in: Schmitter/-Lehmbruch 1979). Nuscheler, F., 1979: Regierung auf Vereinbarung der »neuen Stände«? Diskussion und Befund des Korporatismus in Grossbritannien, in: Zeitschrift für Parlamentsfragen 10, s. $503 \mathrm{ff}$.

Offe, C., 1979 a: »Unregierbarkeit«. Zur Renaissance konservativer Krisentheorien, in: Habermas J. (udg.), Stichworte zur 'Geistigen Situation der Zeit', bind 1, Frankfurt am Main, s. 294ff.

Offe, C., 1979 b: Die Institutionalisierung des Verbandseinflusses - eine ordnungspolitische Zweckmühle, in: v. Alemann/Heinze (1979 c), s. $72 \mathrm{ff}$.

Pahl, R.E./Winkler, J.T., 1974: The Coming corporatism, in: New Society, 10. okt. 1974, 72-76.

Pahl, R.E./Winkler, J.T., 1976: Corporatism in Britain, in: The Corporate State - Reality by Myth? A symposium (sept. 1976), udgivet af Centre for Studies in Social Policy (nu: Policy Studies Institute), London, s. $5 \mathrm{ff}$.

Panitch, L., 1977: The Development of Corporatism in Liberal Democracies, in: Comparative Political Studies, vol. 10, no. 1, april 1977, s. 61-90 (nu: in: Schmitter/Lehmbruch 1979).

Panitch, L., 1979 a: Recent Theorizations of Corporatism: Reflections on a Growth Industry, papir til den 9. verdenskongres for sociologi, Uppsala, august, (mangfoldiggjort manus).

Panitch, L., 1979 b: Trade Unions and the Capitalist State: Corporatism and its Contradictions, papir til en international konference over »The State and the Economy«, Erindale College, University of Toronto, dec., (mangfoldiggjort manus). 
Rokkan, S., 1966: Norway: Numerical Democracy and Corporate Pluralism, in: Dahl,

R.A. (udg.), Political Opposition in Western Democracies, New Haven, s. 70ff.

Ruin, O., 1974: Participatory Democracry and Corporativism: The Case of Sweden, in:

Scandinavian Political Studies, vol. 9, 1974, s. 171ff.

Schmitter, Ph. C., 1974: Still the Century of Corporatism? in: The Review of Politics, vol. 36 no. 1, jan. 1974, s. 85ff. (nu in: Schmitter/Lehmbruch, udg. 1979).

Schmitter, Ph. C., 1977: Modes of Interest Intermediation and Models of Social Change in Western Europe, in: Comparative Political Studies, vol. 10 No. 1, april 1977, s. 3-6/7-38 (nu in: Schmitter/Lehmbruch, udg. 1979).

Schmitter, P.C., 1979 b: Interessenvermittlung und Regierbarkeit, in: Alemann, U.v./Heinze, R. G. (udg.), 1979 c, s. $92 \mathrm{ff}$.

Schmitter, P.C., 1981: Concluding Remarks, in: Lehmbruch, G./Schmitter, P. C.: Consequences of Corporatist Policy Making, London: Sage, i.E.

Schmitter, P.C., Lehmbruch, G. udg., 1979: Trends Toward Corporatist Intermediation, London: Sage.

Shonfield, A., 1965: Modern Capitalism. The Changing Balance of Public and Private power, Oxford University Press, London.

Valentin, F., 1978: Corporatism and the Danish Welfare State, in: Acta Sociologica (Journal of the Scandinavian Sociological Association), Supplement: special issue presented to the 9th World Congress of Sociology, s. $73 \mathrm{ff}$.

Wassenberg, A., 1978 a: Creeping Corporatism: A Cuckoo's Policy, papir til ECPR-Workshop »Corporatism in Liberal Democracies «i Grenoble, april 1978, (mangfoldiggjort manus).

Wassenberg, A., 1978 b: The Researchability of Corporatism, papir til den 9. verdenskongres for sociologi, Uppsala, august 1978, (mangfoldiggjort manus).

Wassenberg, A., 1978 c: Emergent Patterns of Corporatism in the Area of Industrial Policy (industries and nations compared). A Research Proposal, diskussionspapir fra 30.8.1978, (mangfoldiggjort manus).

Westergaaard, J., 1977: Class, Inequality and 'Corporatism', in: Hunt, A. ed., Class \& Class Structure, London, s. 165ff.

Winkler, J. T., 1976: Corporatism, in: Archives Européennes de Sociologie, vol. 17 no. 1, s. $100 \mathrm{f}$. Winkler, J. T., 1977 a: The Corporate Economy: Theory and Administration, in: Scase, R., ed., Industrial Society: Class, Cleavage and Control, London, s. 43ff.

Winkler, J. T., 1977 b: The Coming Corporatism, in: Skidelsky, R. ed., The End of the Keynesian Era. Essays on the Desintegration af the Keynesian Political Economy, London/Basingstoke, s. $78 \mathrm{ff}$.

Litteraturliste fortsat fra side 56 :

Schudlich 1980: Edwin Schudlich, Zum Verhältnis von gewerkschaftlicher Tarifpolitik und betrieblicher Lohnpolitik, in:: WSI-Mitteilungen Nr. 2/1980

Semmler 1981: Willi Semmler, Langfristige Ursachen der gegenwärtigen amerikanischeen Krise und neuere Tendenzen in der Wirtschaftspolitik in den USA, in PROKLA Nr. 42/1981

Sengenberger 1978: Werner Sengenberger (Udg.); Der gespaltene Arbeitsmarkt, Ffm/New York 1978

Streeck 1979: Wolfgang Streeck, Gewerkschaftsorganisation und industrielle Bezeihungen, in: Gewerkschaftliche Monatshefte Nr. 11/1979

Trentin 1978: Bruno Trentin, Arbeiterdemokratie, Hamburg 1978

Vetter 1981: Heinz Oskar Vetter, Einigkeit im Grundsatz, Vielfalt in der Praxis, in: Gewerkschaftliche Monatshefte Nr. 2/1981

Weltzmüller 1980: Rudi Welzmüller, Zur Entwicklung der Löhne und Gehälter in Industrie und Handel - Eine Auswertung der Verdienststatistik, in: WSI-Mitteilungen Nr. 2/1980 Zeuner 1969: (Bodo Zeuner), Untersuchungsbericht über Betriebsratswahlen in Berlin, cit. in: o.A., »Eine solche Konferenz gab es noch nie«, in: Der Gewerkschafter, Nr. 7/1979, S. $20 f$. 
Andre skrifter af GYÖRKY MARKUS og fra BUDAPEST-SKOLEN fra Kurasje's Bogimport:

* G. Markus: 'Anthropologie' und Marxismus. 176. 88,- kr.

Die Neue Linke in Ungarn, bd. 1, 225 s. 36,- kr.

Die Neue Linke in Ungarn, bd. 2, 190 s. 48,- kr.

Af Agnes Heller.

* Das Leben ändern - Radikale Bedürfnisse, Frauen, Utopie. 240

s. 79,- kr.

Theorie der Gefühle, 342 s. 79,- kr..

Theorie der Bedürfniss bei Marx, 151 s. 64,- kr.

Instinkt, Agression, Charakter - Einleitung zu einer marxistischen Sozialanthropologie, 176 s. 64,- kr.

Philosophie des Linken Radikalismus, 180 s. 72,- kr.

Af FERENC FEHER \& AGNES HELLER:

* Diktatur über die Bedürfnisse - Sozialistische Kritik osteeuropäischer Gesellschaftsformationen, 180 s. 72,- kr.

* Ungarn '56 - Geschichte einer antistalinistischen Revolution, 180 s. ca. 125,- kr.

(* betyder nyhed)

INDBETAL BELØBET PÅ GIRO 71660 44, KURASJE, Krystalgade 16 - Husk at angive titel.

BEMARK ABONNENTER PA TIDSSKRIFTET KURASJE FÅR 20\% RABAT PÅ ALLE OVENSTÅENDE PRISER - LIGESOM PÅ ALLE ANDRE BØGER FRA KURASJES BOGIMPORT - TEGN DERFOR ABONNEMENT. 